\title{
The role of principal leadership in improving the quality of learning in elementary school
}

\author{
Supriyono Supriyono $^{1}$, Happy Fitria ${ }^{2}$, Alfroki Marta ${ }^{3}$ \\ ${ }^{1}$ Sekolah Menengah Pertama Negeri 1 Plakat Tinggi, Indonesia \\ ${ }^{2}$ Universitas PGRI Palembang, Indonesia
}

\begin{tabular}{l} 
Article Info \\
\hline Article history: \\
Received Jul $12^{\text {th }}, 2021$ \\
Revised Aug $16^{\text {th }}, 2021$ \\
Accepted Aug $30^{\text {th }}, 2021$ \\
\hline
\end{tabular}

\section{Keyword:}

Principal leadership Learning quality

\begin{abstract}
The leadership role of the principal in improving the quality of learning at SDN 3 Makarti Jaya, Banyuasin Regency can be said to have played a role in improving the quality of learning.As educators, school principals guide teachers how to deliver effective and efficient learning materials, as managers of principals able to optimize educational facilities, as administrators able to compile programs, as a supervisor able to compile an educational supervision program, as a headmaster leader Understand the condition of the school community, as an innovator able to implement reform (change for the better), as a motivator to be able to regulate the work / learning atmosphere, as an intreprenuer of the principal together with the school committee to work together to work creatively in extracting sources of empowerment to improve teacher professionalism, especially with regard to teachers to attend professionalism education and training as well as sending teachers to attend seminars.
\end{abstract}

(C) 2021 The Authors. Published by IICET

This is an open access article under the CC BY-NC-SA license (https://creativecommons.org/licenses/by-nc-sa/4.0

\section{Corresponding Author:}

Supriyono, S.,

Sekolah Menengah Pertama Negeri 1 Plakat Tinggi, Indonesia

Email: entrimujyonosmp1@gmail.com

\section{Introduction}

Principals who are successful when they understand the existence of the school as a complex and unique organization, and able to carry out the role of the principal as a supervisor who is given responsibility for leading the school. The achievement of educational goals is highly dependent on the skills and leadership policies of the principal as a supervisor who is one of the education leaders [1].

With the professionalism of the principal as a supervisor for the professional development of educational personnel it is easy to do because it is in accordance with their function, The principal understands the needs of the school he leads so that the competence of the teacher is not only the competence he had before,but increasing and developing well so that the professional performance of teachers will be realized [1]

[2] There are several factors that make a leader increase the professionalism of his subordinates. First, the leader meets the needs of his subordinates with regard to job effectiveness. Second, leaders provide the training, guidance and support their employees need.

A quality school is an educational institution that builds people's trust in choosing this educational institution as a place to study for their children.Therefore, every educational institution is required to always improve the quality of its education. Because referring to the Government Regulation of the Republic of 
Indonesia Number 19 of 2005 National Education Standards,Article 91 Paragraphs 1 and 2 state that: "Every education unit in the formal and non-formal channels is obliged to guarantee the quality of education.

The education quality assurance as referred to in paragraph (1) aims to meet or exceed the National Education Standards." Referring to the Regulation of the Minister of National Education of the Republic of Indonesia Number 13 of 2007 concerning Standards for Principals of Schools or Madrasahs, that the principal must at least be able to function as educators, managers, administrators, supervisors, leaders, innovators, motivators and entrepreneurs [3].

Thus, schools which are formal educational institutions are directed to improve the quality of education.According to Nata, what is meant by the quality of education is education which all components and various other supporting devices can satisfy students, leaders,teachers and society at large. This quality component, among others, is related to the curriculum or lessons provided, the teaching and learning process, teaching staff, facilities and infrastructure, environment, management (Nata, 2013: 51).

Quality problems in an educational institution are the most serious problems.On average, there are still many educational institutions that have not succeeded in realizing the quality of education.In fact, the quality of education is the common goal of all educational thinkers and practitioners, and has even been pursued through various means, methods, approaches, strategies and policies (Hidayat, 2013: 24).

But in reality, currently the quality of learning at SD Negeri 3 Makarti Jaya is still not considered good.The quality of learning is still considered low, this condition can be assessed in terms of infrastructure, curricula, programs, media and tools to support readiness in achieving quality learning. If the infrastructure, curriculum, programs, media and tools as supporting facilities are not fulfilled, the quality of learning is still low.So that it will affect the learning process that will be conveyed to students.

Based on the background description above, the problem is the lack of leadership role played by the principal in improving the quality of learning.In the learning process it is assisted by educators and education staff with a total of 18 teachers consisting of 11 PNS teachers and 7 honorary teachers.Educational staff as many as 4 people. Of the 11 PNS teachers who already have teaching certificates, 5 are PNS teachers (45.46\%) and 6 PNS teachers (54.54\%) do not have educator certificates.

The learning process is carried out in the morning starting at $07.00 \mathrm{WIB}$ until 12.30 WIB, while extracurricular activities are carried out on Saturdays starting at 07.00 WIB until 12.00 WIB,consisting of 12 (twelve) study groups. at SDN 3 Makarti Jaya trying to improve the quality of education.The principal in carrying out duties refers to the vision, mission and goals of the school. SDN 3 Makarti Jaya was founded and has been operating since 1974.SDN 3 Makarti Jaya has a land area of 5,150 M2, a building area of 2,487 M2, open land which is still available covering an area of 2,663 M2. Other supporting facilities at SDN 3 Makarti Jaya have classrooms and non-classrooms, 11 classrooms with an area of $7 \mathrm{~m} \mathrm{x} 8 \mathrm{~m}$ in good condition. Besides that, other learning support rooms to improve the quality of education at SDN 3 Makarti Jaya have the principal's room, teachers' room, local library, prayer room, warehouse, canteen, UKS

\section{Method}

This study uses qualitative research methods which are field research, namely research carried out directly in the field to obtain the necessary data. This research is specifically designed to describe the phenomena faced, namely social phenomena related to strategies to improve the quality of education in SD Negeri 3 Makarti Jaya, Banyuasin district. The informants who will be interviewed in this study are the principal of SDN 3 Makarti Jaya, Banyuasin district and teachers who teach related to the leadership role of the principal in improving the quality of learning at SDN 3 Makarti Jaya. The reason the researchers conducted research in this place was because the quality of education at SD Negeri 3 Makarti Jaya, Banyuasin district needed to be improved. Collecting data in this study using interviews, observation and documentation.Then analyzed by triangulation rules, source triangulation to test the credibility of the data is done by checking the data that has been obtained through several sources or informants. This is done until the data trend is obtained so that the data can be viewed as containing truth values.

\section{Results and Discussions}

Based on the results of research through interviews as a source of primary data to the principal and 6 class teachers at SDN 3 Makarti Jaya, Banyuasin Regency, that as an educator the principal has played a role in improving the quality of learning at SDN 3 Makarti Jaya, Banyuasin Regency.This is carried out by activities carried out by the principal in character building based on the values of educators including: (1) Providing 
understanding to students;(2) fostering teachers how to deliver effective and efficient learning materials; (3) To provide guidance for teachers to be able to develop their potential in teaching, and (4) To train teachers to keep abreast of developments in the field of education.

The principal as a manager in managing resources to achieve institutional goals effectively and efficiently, namely: (1) the principal's ability to prepare programs; (2) The ability of the principal to organize school organizations; (3) The principal's ability to mobilize teachers; and (4) the ability of the principal in optimizing educational facilities. Principal plays a role in managing resources to achieve institutional goals effectively and efficiently, which includes: (1) Ability to compile programs; (2) Ability to organize school organizations; (3) Ability to move teachers; and (4) Ability to optimize educational facilities.

Principal's Role as Supervisor. The principal has a role in helping to improve the performance of teachers and other education personnel, which includes: (1) Ability to compile educational supervision programs; (2) Ability to carry out the supervision program; and (3) Ability to take advantage of the results of supervision.

Role of Principal as Leader. The principal plays a role in influencing people to work together in achieving a common vision and goals, which include: (1) Having a strong personality; (2) Ability to provide clean, transparent and professional services; and (3) Understanding the condition of the school community.

Principal's Role as Innovator. The principal is a dynamic and creative person who does not get caught up in routine. Ability to implement reform (change for the better).Ability to implement the latest policies in the field of education.

The Principal's Role as a Motivator. The principal must be able to provide encouragement so that all components of education can develop professionally through: (1) Ability to regulate the work environment (physical); (2) The ability to regulate the work / learning atmosphere, and (3) The ability to give decisions to school members.

The learning process delivered by the teacher in each class who is taught in educating students at SDN 3 Makarti Jaya, Banyuasin Regency, can be said that most of the teachers are good at carrying out their duties as teachers.It is known from the results of interviews obtained from each class teacher, that the teacher said that he had planned in advance to prepare the learning tools. The teacher said that the lesson plans made were reported to the principal and approved. The teacher said that the lesson plans made were in accordance with the curriculum.

The teacher said that in planning lessons he did not report to the principal. The teacher said that in implementing learning it was in accordance with the learning device guidelines. The teacher said that in carrying out the learning process there were those who often used props and some said that it depends on the learning material delivered whether it is necessary to use props or not. The teacher said that when carrying out the learning process there were those who used companion books in addition to handbooks, some only relied on handbooks.

The teacher said that in carrying out the learning process, he had conducted learning activities outside the classroom and there were also teachers who said they had never carried out learning activities outside the classroom in carrying out the learning process. The teacher said that he always evaluates the learning outcomes at the end of each lesson. The teacher said that he always evaluates the learning outcomes in the middle of the semester. The teacher said that he always evaluates the learning outcomes per semester.The teacher said that he always evaluates the learning outcomes at the end of the learning year (UKK). The teacher said that when delivering the learning material it was in accordance with the planning of learning activities. The teacher said that in the learning process he conveyed trying to make students active and creative in following the lesson. The teacher said that the materials he delivered used tools / props as a learning resource, some rarely used them. The teacher said that in delivering learning material through media / tools, it was trying to make students understand the material. The teacher said that he would provide guidance to students who had difficulty learning.

The teacher said that he would provide directions to students to bring handbooks when participating in learning activities. The teacher said that they provide guidance and counseling if there are students who often do undisciplines. The teacher said that he had provided guidance and counseling to students who had interests and talents and provided motivation so that students were encouraged to achieve achievements.

The leader of a school who is finally called the Principal, in the context of the principal's duties are very heavy because he must be able to play a dual role. Apart from being a leader, of course, they are able to become partners of teachers in teaching and educating their students. And of course every leader has his own way and method of carrying out his duties and functions. 
In order for the process to run smoothly, the leader must treat the individual humanely. Humans in carrying out their activities are always influenced by different personalities, for example traits, attitudes, values, desires and interests, for this it will affect their leadership role as well as in their work.

For this reason, the principal must be able to create a work atmosphere that is supported by his subordinates to always work professionally. Not misusing for personal gain, but to achieve individual goals in the organization so that the work performance of subordinates can be improved and organizational goals can be achieved more effectively and efficiently (Hendarman, 2018: 11).

[2] There are several factors that make a leader increase the professionalism of his subordinates. First, the leader meets the needs of his subordinates with regard to job effectiveness. Second, leaders provide the training, guidance and support their employees need.

In an effort to increase the professionalism of subordinates, the role of leadership is very important, because the success or failure of an achieved goal depends on the leadership. And this is an obligation for each leader to be able to lead his subordinates to work in accordance with the instructions given so that it will create conditions and a work environment that encourages activities to achieve organizational goals effectively and efficiently.

[2] Professional teachers are believed to be able to lead students in learning to find, manage, integrate their acquisition, and solve problems related to knowledge, attitudes, and values or life skills. Professional teachers are believed to be able to make students think, behave and act creatively.

Teacher is a professional job that requires special skills as an educator / teacher. This type of work cannot be done by anyone outside the field of education. Tasks include educating teachers as a profession, teaching and training.

Teachers are educators whose main task is to teach, in the sense of developing the realm of creativity, feeling and the will of students as the implementation of the ideal concept of education. Teacher personality characteristics include: cognitive flexibility, and psychological openness. We hope that teachers are able to compete and work professionally.

[4] Professional teachers are the key to smoothness and success in the learning process in schools. Because only professional teachers can create active situations for students in learning activities. [5] Eeducation personnel have a very strategic role in forming the knowledge, skills and character of students. Therefore, professional education personnel will carry out their duties professionally so as to produce higher quality graduates.

Based on relevant research, it also strengthens studies in this research such as research [6] The Role of School Principals in Improving Teacher Professionalism in Junior High School (SMP) Muhammadiyah 3 Kaliwungu and SMP Muhammadiyah 6 Kendal".The results of his research stated that: 1) the implementation of the role of the principal in the two schools in general had no significant difference. The roles of educators, school managers, administrators, supervisors, leaders, climators, motivators, innovators, entrepreneurs have been implemented well. However, the role as an entrepreneur / innovator has not been maximally carried out,because at SMP Muhamadiyah 3 Kaliwungu is constrained by the availability of limited funds for the completeness of school infrastructure, the lack of student tutoring facilities so that when participating in academic competitions, public schools always lose out, but stand out in the non-academic field.Meanwhile, at SMP Muhammadiyah 6 Kendal is also constrained by limited funds, lack of creativity in creating a pleasant teaching atmosphere; 2) The professionalism of the teachers in the two schools so far has had sufficient numbers of teachers, each teaching teacher has been adjusted according to their educational qualifications.In terms of performance quality, in general, they are quite disciplined and agile; 3) the efforts made by the principal in increasing the professionalism of teachers in the two schools by making school work plans for 4 years and 1 year in terms of educators and education personnel, and implementing various efforts to increase teacher professionalism, including:

fostering work discipline, providing motivation and appreciation, establishing good working relationships, providing and fulfilling welfare and occupational safety guarantees, providing self-actualization and selfdevelopment needs, participating in educational training, participating in MGMP, seminars, workshops, education and training, further education, and teacher certification program.This study can be concluded that there are similarities and differences made by previous researchers with current research, namely both studying school principals. Whereas the difference between previous research and current research is that it lies in the object used as the source of research data and the place of research. 
Syukri's research (2017) entitled "The Role of Principal Leadership in Improving Teacher Performance at Nurul Ihsan Middle School, Tolitoli Regency, Central Sulawesi." The results of this study indicate that the leadership role of the head of SMP Nurul Ihsan in carrying out his duties with full responsibility,with the aim of improving teacher performance, by taking a normative approach or motivating teachers to always work in accordance with their duties, with expertise in the field of study being taught,planning, coordination and evaluation, with the implementation of this ultimately all the intentions will be realized that to support all principal programs in improving performance are external and internal factors, facilities and infrastructure, methods and programs. What this research has in common with the current research is that they both examine the leadership of the principal and teacher performance. The difference is, Syukri (2017) examined the Role of Principal Leadership in Improving Teacher Performance at Nurul Ihsan Middle School, Tolitoli Regency, Central Sulawesi, while this study examined the leadership role of school principals in improving the quality of learning at SDN 3 Makarti Jaya, Banyuasin Regency.

\section{Conclusions}

The data of learning habits were collected by using a questionnaire. The maximum score of test was 175 , the minimum score of test was 116, and the range was 59. The mean (or the average score) and standard deviation were 146,85 and 14,644 respectively. The results for the variable Students Learning Styles (X1) obtained coefficient $B=-0.003$ and calculate the tobtained $=-0,097$ or $p$-value $=0.923$, because $0.923>0.05$. Ha was rejected, the error level $\alpha=0.05$ or $5 \%$, Ho was accepted. It can be stated that Students Learning Habits (X1) simultaneously have no significant correlated the Reading Comprehension (Y). The results for the variable Students Learning Motivation (X2) obtained coefficient B $=-0.031$ and calculate the tobtained $=-0,462$ or $\mathrm{p}$ value $=0.645$, because $0.645>0.05$. Ho was accepted, the error level $\alpha=0.05$ or $5 \%$, Ha was rejected. It can be stated that Students Learning Motivation (X2) simultaneously have no significant correlated the Reading Comprehension (Y)

\section{References}

Wahjosumidjo. 2016. Organisasi, Kepemimpinan \& Prilaku Administrasi. Jakarta: Gunung Agung. Mulyasa. 2013. Manajemen dan Kepemimpinan Kepala Sekolah. Jakarta: Bumi Aksara.

Danim, S. 2010. Profesionalisasi dan Etika Profesi Guru. Bandung: Alfabeta.

Sukadi. 2016. Guru dan Masa Depan. Jakarta: Rajawali Press.

Zahroh, Aminatul. 2015. Membangun Kualitas Pembelajaran Melalui Dimensi Profesionalisme Guru. Bandung: Yrama Widya.

Nurul, L.I. 2014. Peran Kepala Sekolah dalam Meningkatkan Profesionalisme Guru di Sekolah Menengah Pertama (SMP) Muhammadiyah 3 Kaliwungu dan SMP Muhammadiyah 6 Kendal. Jurnal Manajemen Pendidikan, Volume 3 Nomor 1 Oktober 2014, Halaman 57-72. 